Науковий вісник Нлту України
Scientific Bulletin of UNFU
http://nv.nltu.edu.ua
https://doi.org/10.15421/40290119
Article received 22.01.2019 p.
Article accepted 28.02.2019 p.
удк 674.8:662.765.1

С. С. Лис, М. М. Семерак, О. Г. Юрасова

Національний університет "Львівська політехніка", м. Львів, Україна

\title{
РОЗРОБЛЕННЯ МЕТОДУ РОЗРАХУНКУ ПРОЦЕСУ ГАЗИФІКАЦІЇ НИЗЬКОСОРТНОГО ПАЛИВА У СУЦІЛЬНОМУ ШАРІ НА ОСНОВІ ЕКСПЕРИМЕНТАЛЬНИХ ДОСЛІДЖЕНЬ
}

Розроблено метод розрахунку процесу газифікації низькосортного палива, який дає змогу провести розрахунок параметрів робочого процесу в газифікаторі зі суцільним шаром, який $є$ найбільш технологічно та конструктивно простим. Проаналізовано фізичні моделі процесу газифікації твердого палива, які дають змогу побудувати методику розрахунку параметрів робочого процесу у газифікаторі, засновану на рівняннях теплового і матеріального балансів, вигорання і газифікації вуглецю, що сприяє підвищенню екологічних показників та модернізації наявних інженерних методів розрахунку. Використано стандартизовані методи проведення досліджень процесу газифікації низькосортного палива. У процесі розроблення газогенераторної установки, що дає змогу виробляти синтез-газ, застосовано сучасні методи використання відповідних контрольно-вимірювальних пристроїв. Використано математичне планування експериментальних досліджень. Розроблено метод розрахунку процесу газифікації деревини, який дає змогу провести розрахунок параметрів робочого процесу в газифікаторі зі суцільним шаром, засновану на рівняннях теплового і матеріального балансів. На основі експериментальних досліджень складено матеріальний і тепловий баланси процесу газифікації деревини породи сосна (Pinus sylvestris). Показано, що під час газифікації соснової деревини невеликі втрати тепла виходять внаслідок винесення пилу і втрат вуглецю із золою і шлаком.

Ключові слова: нижча теплота згорання; синтез-газ; матеріальний і тепловий баланси; газифікація низькосортного палива.

Вступ. Склад і теплотворна здатність синтез-газу, отримуваного внаслідок газифікації низькосортного палива, можуть змінюватися залежно від різних факторів. Основними факторами, які впливають на процес газифікації деревини, є розміри частинок, кількість повітря, поданого в камеру газифікації і низка інших факторів, залежних від палива, яке газифікується, і параметрів газифікатора.

Реалізація програми розроблення методів моделювання процесів газифікації деревини сприяє підвищенню екологічних показників, скороченню термінів розроблення агрегатів, модернізації наявних інженерних методів розрахунку та проектування обладнання, пошуку оптимальних умов функціонування апаратів та раціональних шляхів використання палив.

Аналіз останніх досліджень. У світі намітилась тенденція до децентралізації вироблення теплової та електричної енергії, тобто використання когенераційних установок (Mysak, Lys \& Martynyak-Andrushko, 2017; Al-Rahbi, Onwudili \& Williams, 2016; Zhang, et al., 2016; López-González, et al., 2014). Перспективними когенераційними установками $є$ двигуни внутрішнього згорання, які працюють на синтез-газі. Тому газифіка- ція низькосортного палива для вироблення синтез-газу $€$ перспективною.

На сьогодні розроблено та висвітлено в літературних джерелах та наукових статтях фізичні моделі процесу газифікації твердого палива (Zhiqiang, et al., 2017; Mingaleeva, Ermolaev \& Galkeeva, 2016; Islam, Faruque \& Zakia, 2016; La Villetta, Costa \& Massarotti, 2017), які дають змогу побудувати методику розрахунку параметрів робочого процесу у газифікаторі, засновану на рівняннях теплового і матеріального балансів, вигорання i газифікації вуглецю, а також теплообміну часток 3 шаром і зі стінкою газогенератора. Проте ці фізичні моделі розроблено для конкретного типу газифікатора. Тому $\epsilon$ потреба розробити метод розрахунку процесу газифікації деревини, яка дасть змогу провести розрахунок параметрів робочого процесу в газифікаторі зі суцільним шаром, який $є$ найбільш технологічно та конструктивно простим.

Виділення невирішених раніше частин загальної проблеми. Оскільки ці (Zhiqiang, et al., 2017; Mingaleeva, Ermolaev \& Galkeeva, 2016; Islam, Faruque \& Zakia, 2016; La Villetta, Costa \& Massarotti, 2017) фізичні моделі розроблено для конкретного типу газифікатора, то

Інформація про авторів:

Лис Степан Степанович, канд. техн. наук, ст. викладач, кафедра теплоенергетики, теплових і атомних електричних станцій. Email: lysss@ukr.net; https://orcid.org/0000-0002-7359-1177

Семерак Михайло Михайлович, д-р техн. наук, професор, завідувач кафедри теплоенергетики, теплових і атомних електричних станцій. Email: lysss@ukr.net; https://orcid.org/0000-0002-7582-6398

Юрасова Оксана Георгіївна, ст. викладач, кафедра теплоенергетики, теплових і атомних електричних станцій. Email: oksjanchyk@gmail.com; https://orcid.org/0000-0001-9930-9152

Цитування за ДСту: Лис С. С., Семерак М. М., Юрасова О. Г. Розроблення методу розрахунку процесу газифікації низькосортного палива у суцільному шарі на основі експериментальних досліджень. Науковий вісник НлТУ України. 2019 , т. 29 , № 1. С. 87-92.

Citation APA: Lys, S. S., Semerak, M. M., \& Yurasova, O. H. (2019). Development of a Method for Calculating the Process of Gasification of Low-Grade Fuels in a Continuous Layer on the Basis of Experimental Research. Scientific Bulletin of UNFU, $29(1), 87-92$. https://doi.org/10.15421/40290119 
потрібно розробити метод розрахунку процесу газифікації деревини, який дасть змогу провести розрахунок параметрів робочого процесу в газифікаторі з суцільним шаром, який $\epsilon$ найбільш технологічно та конструктивно простим. Для цього потрібно здійснити комплекс досліджень 3 використанням сучасної методології та досягнень сучасної науки і техніки. Найбільш технологічно, конструктивно простим та інтенсивним способом газифікації деревини є газифікація в реакторі зі суцільним шаром (Mysak, Lys \& Martynyak-Andrushko, 2017; Tapas \& Sheth, 2015; Hejazi, et al., 2017; Lys, 2017a, 2017b; Lopez, et al., 2016). Перевагами газифікаторів зі суцільним шаром є: високий ступінь перетворення вуглеводню, мала кількість золи, тривале перебування твердого палива в реакторі, достатньо проста конструкція газифікатора.

Мета і завдання дослідження. Метою дослідження $\epsilon$ розробити метод розрахунку процесу газифікації низькосортного палива, який дасть змогу провести розрахунок параметрів робочого процесу в газифікаторі зі суцільним шаром, який $є$ найбільш технологічно та конструктивно простим.

Для досягнення поставленої мети потрібно виконати такі завдання:

- проаналізувати фізичні моделі процесу газифікації низькосортного палива;

- розробити метод розрахунку процесу газифікації низькосортного палива у суцільному шарі;

- скласти матеріальний і тепловий баланси на основі експериментальних досліджень процесу газифікації низькосортного палива у суцільному шарі.

Матеріали та устаткування, що використані в експериментальних дослідженнях. Для проведення експериментальних досліджень використовували такі матеріали: деревина породи сосна (Pinus sylvestris). Завдання полягало у знаходженні залежності нижчої теплоти згорання синтез-газу від кількості повітря та кількості палива під час газифікації деревини породи сосна.

Для проведення експериментальних досліджень та розроблення технологічного процесу вироблення синтез-газу розроблено газогенератор зі суцільним шаром (Mysak, Lys \& Martynyak-Andrushko, 2017; Lys, 2017a).
Сучасні відомі газогенератори зі суцільним шаром дають змогу отримувати синтез-газ з теплотворною здатністю 5,0-7,5 МДж/нм³ газифікується, та складні в обслуговуванні. Завданням було розробити таку конструкцію газогенератора, яка дала б змогу отримувати синтез-газ з більшою теплотворною здатністю, газифікувати паливо з більшою вологістю та була нескладною в експлуатації.

Використання газогенераторів запропонованої конструкції, як показали дослідження, дає змогу підвищити ефективність роботи шляхом збільшення швидкості та інтенсивності процесу газифікації подрібненої деревини. Це досягається завдяки тому, що гази, які утворилися під час газифікації, повторно проходять через шар розжареного палива в зоні окислення та відновлення, де за високих температур відбувається гетерогенна реакція відновлення двоокису вуглецю, тобто $\mathrm{C}+\mathrm{CO}_{2} \rightarrow 2 \mathrm{CO}$ та утворюється горючий складник синтез-газу - оксид вуглецю. Якщо в зоні відновлення є водяна пара, то за високої температури відбувається реакція іiї конверсії, тобто $\mathrm{C}+\mathrm{H}_{2} \mathrm{O} \rightarrow \mathrm{CO}+\mathrm{H}_{2}$ та $\mathrm{CO}+\mathrm{H}_{2} \mathrm{O} \rightarrow \mathrm{CO}_{2}$ $+\mathrm{H}_{2}$. У цьому випадку утворюється другий горючий складник синтез-газу - водень (Mysak, Lys \& Martynyak-Andrushko, 2017; Zhang, et al., 2016; Lys, 2017b). Отже, завдяки значному вмісту оксиду вуглецю та водню в синтез-газі нижча теплота згорання є відносно досить високою.

Методика оброблення результатів експериментальних досліджень. У серії дослідів завдання полягало у знаходженні залежності нижчої теплоти згорання синтез-газу від кількості повітря та кількості палива в камері газифікації (табл. 1).

Кількість дослідів, що дублювалися в кожній серії, $n$ = 6. Дані кожного досліду піддавались статистичній обробці для відшукання грубих помилок, сумнівні результати перевірялись за допомогою $t$-критерію Стьюдента. Сумнівний результат тимчасово виключали із вибірки, а за даними, що залишились, розраховували середнє арифметичне і оцінку дисперсії (Mysak, Lys \& Martynyak-Andrushko, 2017).

Табл. 1. Експериментальні дані роботи газогенератора під час газифікації деревини породи сосна (Pinus sylvestris) розміром частинок 30 мм

\begin{tabular}{|c|c|c|c|c|c|c|c|c|c|c|c|}
\hline \multirow[b]{2}{*}{$\begin{array}{l}\text { № } \\
3 / \Pi\end{array}$} & \multirow{2}{*}{$\begin{array}{l}\text { Кількість } \\
\text { повітря, } \\
\text { нм }^{3} / \text { год }\end{array}$} & \multirow{2}{*}{$\begin{array}{c}\text { Кількість па- } \\
\text { лива в газоге- } \\
\text { нераторі, \% }\end{array}$} & \multirow{2}{*}{$\begin{array}{c}\text { Нижча тепло- } \\
\text { та згорання } \\
\text { синтез-газу, } \\
\text { МДж/м }\end{array}$} & \multirow{2}{*}{$\begin{array}{c}\text { Темпера- } \\
\text { тура на } \\
\text { колосни- } \\
\text { ку, }{ }^{0} \mathrm{C}\end{array}$} & \multirow{2}{*}{$\begin{array}{c}\text { Температура } \\
\text { синтез-газу на } \\
\text { виході } 3 \text { газоге- } \\
\text { нератора, }{ }^{0} \mathrm{C}\end{array}$} & \multicolumn{6}{|c|}{ Склад синтез-газу, \% } \\
\hline & & & & & & $\mathrm{H}_{2}$ & $\mathrm{CO}$ & $\mathrm{CO}_{2}$ & $\mathrm{CH}_{4}$ & $\mathrm{~N}_{2}$ & $\mathrm{O}_{2}$ \\
\hline 1 & 40 & 50 & 8,403 & 1193 & 124 & 21,8 & 29,9 & 8,4 & 6,3 & 33,5 & 0,1 \\
\hline 2 & 40 & 75 & 8,995 & 1211 & 117 & 22,3 & 30,2 & 7,8 & 6,9 & 32,7 & 0,1 \\
\hline 3 & 40 & 100 & 8,695 & 1202 & 108 & 22,8 & 30,8 & 7,3 & 7,2 & 31,8 & 0,1 \\
\hline 4 & 65 & 50 & 9,289 & 1213 & 127 & 24,7 & 31,5 & 6,2 & 7,5 & 29,9 & 0,2 \\
\hline 5 & 65 & 75 & 9,875 & 1219 & 118 & 25,9 & 32,8 & 5,3 & 7,7 & 28,1 & 0,2 \\
\hline 6 & 65 & 100 & 9,636 & 1215 & 101 & 25,2 & 32,4 & 5,7 & 7,6 & 28,9 & 0,2 \\
\hline 7 & 90 & 50 & 8,810 & 1223 & 131 & 22,9 & 30,9 & 7,1 & 7,6 & 31,3 & 0,2 \\
\hline 8 & 90 & 75 & 9,430 & 1236 & 122 & 24,4 & 32,5 & 6,1 & 7,5 & 29,3 & 0,2 \\
\hline 9 & 90 & 100 & 9,185 & 1231 & 117 & 24,5 & 32,1 & 5,8 & 7,3 & 30,1 & 0,2 \\
\hline
\end{tabular}

У матеріальному балансі процесу газифікації деревини в газогенераторі зі суцільним шаром на основі закону збереження речовини зіставляють кількість речовин, введених у газогенератор і виведених з нього. Облік речовин ведеться за елементами. Для складання матеріального балансу необхідно знати склад палива, газу та відходів.

Під час розрахунку матеріального балансу враховують, що всі складові частини палива реагують у процесі газифікації. Вміст у газі окремих елементів визначають на основі того, що 1 кг'моль будь-якого газу займає об'єм 22,4 нм ${ }^{3}$ за температури $0{ }^{\circ} \mathrm{C}$ і тиску 760 мм рт.ст.

Об'єм 1 моля деяких реальних газів відрізняються від величини 22,4 нм ${ }^{3}$. Для водню, наприклад, об'єм 1 моля дорівнює $22,42 \mathrm{Hм}^{3}$, що враховано у визначенні вмісту водню в газах.

Вміст вуглецю в $1 \mathrm{Hм}^{3} \mathrm{CO}_{2}$ : 


$$
C=12 / 22,4=0,536 \kappa г / \mathrm{Hм}^{3},
$$

де 12 - молекулярна маса вуглецю, кг/кмоль.

Вміст кисню в $1 \mathrm{Hм}^{3} \mathrm{CO}_{2}$ :

$$
\mathrm{O}_{2}=32 / 22,4=1,429 \kappa \mathrm{\kappa} / \mathrm{нм}^{3} \text {, }
$$

де 32 - молекулярна маса кисню, кг/кмоль.

У табл. 2 наведено вміст елементів у різних газах.

Табл. 2. Вміст елементів у різних газах

\begin{tabular}{|c|c|c|c|c|}
\hline \multirow{2}{*}{ Газ } & \multicolumn{4}{|c|}{ Вміст елементів в 1 нм$^{3}$ газу в кг } \\
\cline { 2 - 5 } & $\mathrm{C}$ & $\mathrm{H}$ & $\mathrm{O}$ & $\mathrm{S}$ \\
\hline $\mathrm{CO}_{2}$ & 0,536 & - & 1,429 & - \\
\hline $\mathrm{O}_{2}$ & - & - & 1,429 & - \\
\hline $\mathrm{CO}$ & 0,536 & - & 0,714 & - \\
\hline $\mathrm{H}_{2} \mathrm{O}$ & - & 0,0899 & 0,714 & - \\
\hline $\mathrm{CH}_{4}$ & 0,536 & 0,1798 & - & - \\
\hline $\mathrm{H}_{2} \mathrm{~S}$ & - & 0,0899 & - & 1,429 \\
\hline
\end{tabular}

Вихід сухого газу визначають на основі балансу вуглецю. $3 C^{p}$ кг вуглецю, який міститься в 1 кг палива, в газ переходить (Zhiqiang, et al., 2017

Mingaleeva, Ermolaev \& Galkeeva, 2016; Islam, Faruque \& Zakia, 2016; Lys \& Mysak, 2012):

$$
C_{Д}^{p}=C^{p}-\left(C_{u}+C_{c M}+C_{n}\right)=C^{p}-C_{6.8 .}, \text { кг/кг палива, }
$$

де: $C_{u}-$ вміст вуглецю в золі і шлаку; $C_{c м}-$ вміст вуглецю у смолі; $C_{n}$ - вміст вуглецю в пилі; $C_{\text {в.в. }}-$ сума втрат вуглецю.

В $1 \mathrm{Hм}^{3}$ сухого синтез-газу міститься вуглецю:

$$
\mathrm{C}=12 / 22,4\left(\mathrm{CO}+\mathrm{CO}_{2}+\mathrm{CH}_{4}\right), \text { кг. }
$$

Тоді, вихід сухого газу дорівнює:

$$
V_{C}=1,867\left(C^{p}-C_{6.8}\right) /\left(C O+\mathrm{CO}_{2}+\mathrm{CH}_{4}\right), \mathrm{HM}^{3} / \kappa г,
$$

де вміст $\mathrm{CO}, \mathrm{CO}_{2}, \mathrm{CH}_{4}$ виражений в \% відносно об'єму газу; $C^{p}$ і $C_{\text {6.6. }}-$ в \% відносно складу палива в робочому стані.

Вологість газу визначають з балансу водню. У процесі газифікації водень вноситься $з$ паливом і з дуттям.

3 сухою частиною палива вноситься $H_{m}^{p}$ кг водню, 3 вологою палива $W^{p} / 9$ кг. У сухому газі вміст водню становитиме:

$$
H^{\Gamma}=0,0899\left(H_{2}+2 C_{4}\right) \cdot V_{C}, \kappa г / \mathrm{HM}^{3} .
$$

Вміст водню у волозі $f_{\Gamma}$ газу буде дорівнювати:

$$
H^{\Gamma}=f_{\Gamma} \cdot V_{C} / 9, \text { кг. }
$$

Вмістом водню у смолистих речовинах можна нехтувати, оскільки смол у синтез-газі є дуже мало.

Вміст вологи в газі визначаємо з балансу водню:

$$
H_{m}^{p}+1 / 9 W^{p}=0,0899\left(H_{2}+2 C H_{4}\right) \cdot V_{C}+f_{\Gamma} \cdot V_{C} / 9,
$$

звідки вологість газу дорівнює:

$f_{\Gamma}=\frac{9}{V_{C}} \cdot\left(H_{m}^{p}+\frac{1}{9} \cdot W^{p}-0,0899 \cdot\left(H_{2}+2 C H_{4}\right) \cdot V_{C}\right)$, кг/нм ${ }^{3}$,

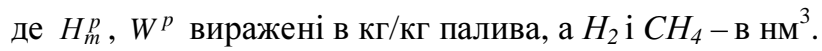

Усі об'ємні величини відносяться до одного стану газу. Вихід вологого газу визначаємо як суму об'ємів сухого газу і водяної пари:

$$
V_{B . \Gamma .}=V_{C}+f_{\Gamma} \cdot \frac{V_{C}}{0,804}=V_{C} \cdot \frac{0,804+f_{\Gamma}}{0,804}, \mathrm{Hм}^{3} / \text { кг. }
$$

Витрату повітря під час газифікації 1 кг палива знаходимо з балансу азоту. Азот вводиться з паливом $N_{2}^{p}$ i повітрям:

$$
N_{2}^{\Pi}=0,79 \cdot V_{\Pi} .
$$

У газі, отриманому з 1 кг палива, $€ N_{2}^{\Gamma} \cdot V_{C}$ нм$^{3}$ азоту. Баланс азоту такий:

$$
0,79 \cdot V_{\Pi}+N_{2}^{p} / 1,25=N_{2}^{\Gamma} \cdot V_{C} .
$$

Звідси витрата повітря на процес газифікації:

$$
V_{\Pi I}=\left(N_{2}^{T} \cdot V_{C}-N_{2}^{p} / 1,25\right) / 0,79, \mathrm{Hм}^{3} / \text { кг палив. }
$$

За незначного вмісту азоту в паливі можна допустити, що $N_{2}^{p}=0$, тоді:

$$
V_{\Pi}=N_{2}^{\Gamma} \cdot V_{C} / 0,79 .
$$

Вміст смол у газі під час газифікації деревини становить $0,5-1,0$ г/нм ${ }^{3}$. Вміст пилу в газі залежить від системи очищення газу i не повинна перевищувати 34 г/нм ${ }^{3}$ під час газифікації деревини. Втрати вуглецю із золою під час газифікації деревини становлять 2-3 \%.

Кількість розкладеної водяної пари на 1 кг палива знаходимо з матеріального балансу води.

Масова частка води, витрачена на утворення $\mathrm{H}_{2} \mathrm{i}$ $\mathrm{CH}_{4}$, становитиме:

$$
w=\left(18 \cdot\left(H_{2}+2 \mathrm{CH}_{4}\right)\right) / 22,4 \cdot 100, \mathrm{\kappa г} / \mathrm{Hм}^{3} \text { газу. }
$$

Витрата води на 1 кг вуглецю, який перейшов у газ, дорівнює:

$$
\begin{gathered}
W=w \cdot V_{C}= \\
=\frac{22,4 \cdot 18 \cdot\left(\mathrm{H}_{2}+2 \mathrm{CH}_{4}\right) \cdot \mathrm{C}_{Д}^{p}}{22,4} \cdot 12\left(\mathrm{CO}+\mathrm{CO}_{2}+\mathrm{CH}_{4}\right), \mathrm{K} .
\end{gathered}
$$

Спростивши рівняння (16), отримаємо:

$$
W=\left(1,5 \cdot\left(\mathrm{H}_{2}+2 \mathrm{CH}_{4}\right) \cdot \mathrm{C}_{\text {Д }}^{p}\right) /\left(\mathrm{CO}+\mathrm{CO}_{2}+\mathrm{CH}_{4}\right), \text { кг. }
$$

Оскільки частина водню в газі утворюється за рахунок вільного водню палива, то масова частка розкладеної водяної пари на 1 кг палива дорівнює:

$$
W_{\text {П.P. }}=\frac{1}{100} \cdot\left(1,5 C_{Д}^{P} \cdot \frac{\mathrm{H}_{2}+2 \mathrm{CH}_{4}}{\mathrm{CO}+\mathrm{CO}_{2}+\mathrm{CH}_{4}}-9 \mathrm{H}_{m}^{p}\right), \mathrm{\kappa} .
$$

У процесі газифікації ступінь розкладу водяної пари становить 40-80\%.

Питому масу вологого газу в кг/нм ${ }^{3}$ визначаємо за формулою

$$
\begin{gathered}
y_{\Gamma}=y_{C O} v_{C O}+y_{C O 2} v_{C O 2}+y_{H 2} v_{H 2}+y_{H 2 O} v_{H 2 O}+ \\
+y_{C H 4} v_{C H 4}+y_{N 2} v_{N 2}+y_{O 2} v_{O 2},
\end{gathered}
$$

де $y_{\mathrm{O} 2}, y_{\mathrm{N} 2}, y_{\mathrm{CH} 4}, y_{\mathrm{H} 2 \mathrm{O}}, y_{\mathrm{H} 2}, y_{\mathrm{CO}}, y_{\mathrm{CO} 2}$ - питома маса компонентів синтез-газу, кг/нм ${ }^{3}$, а $v_{O 2}, v_{N 2}, v_{C H 4}, v_{H 2 O}$, $v_{H 2}, v_{C O}, v_{C O 2}-$ відносний об'ємний вміст компонентів у синтез-газі.

За приходом і витратою тепла в процесі газифікації можна оцінити розподіл всіх втрат тепла (Lys \& Mysak, 2012; Moltó, et al., 2013).

Приходом теплового балансу є:

- теплотворність робочого палива, що бере участь у процесі газифікації;

- тепло нагрітого палива;

• тепло підігрітого повітря

Витратою теплового балансу є:

- теплотворність газу, який отримується з 1 кг палива;

- кількість тепла, що витрачається на нагрів газу, що виходить 3 газогенератора, залежне від температури газу і теплоємності його компонентів;

- теплотворність недопаленого вуглецю, що втрачається із золою і шлаком;

- втрати тепла в навколишнє середовище;

- втрати тепла у смолі і пилі, що виносяться з газогенератора разом з потоком газу.

Тепловий баланс зазвичай складають за нижчою теплотворністю палива і газу. Температуру відраховують від $0{ }^{\circ} \mathrm{C}$. Нижча теплотворність палива визначається розрахунковим або аналітичним методом. 
Аналітично теплотворність палива визначаємо за допомогою калориметра.

Тепло, що витрачається на підігрів повітря, визначаємо залежно від температури (Lys \& Mysak, 2012):

$$
Q_{\text {пов. }}=g_{\text {пов. }} c_{p} t_{\text {пов. }}, \mathrm{\kappa Дж/кг,}
$$

де: $g_{\text {пов. }}-$ масова витрата повітря у процесі газифікації 1 кг палива, кг; $c_{p}$ - теплоємність повітря, кДж/(кг $\left.{ }^{\circ} \mathrm{C}\right)$; $t_{\text {пов. }}$ - температура повітря, ${ }^{\circ} \mathrm{C}$.

У витратній частині теплового балансу найбільшу величину становить теплотворність газу, що отримується під час газифікації палива. Теплотворність газу може бути визначена розрахунковим або калориметричним методом.

Теплотворність сухого газу розраховуємо за таким рівнянням:

$$
Q_{H}^{c .2}=127,7 \cdot \mathrm{CO}+107,6 \cdot \mathrm{H}_{2}+356,9 \cdot \mathrm{CH}_{4}, \mathrm{\kappa Д} / \mathrm{Hм}^{3},
$$

де $\mathrm{CO}, \mathrm{H}_{2} \mathrm{i} \mathrm{CH}_{4}$ - вміст у газі окису вуглецю, водню $\mathrm{i}$ метану в \% відносно об'єму. Теплотворність вищих вуглеводнів у цьому рівнянні не враховується.

Теплотворність вологого газу:

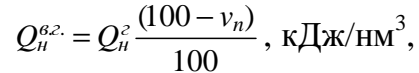

де $v_{n}-$ відносний об'єм пари у складі вологого газу.

Кількість тепла, що витрачається на підігрів газу, який отримується 31 кг палива, знаходимо за рівнянНяМ

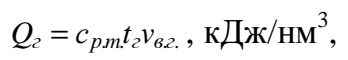

де: $c_{p m}$ - середня теплоємність $1 \mathrm{~m}^{3}$ вологого синтез-газу в кДж/ $\left(\mathrm{Hм}^{3} \cdot{ }^{0} \mathrm{C}\right) ; t_{2}-$ температура газу на виході з газогенератора; $v_{\text {в.. }}-$ вихід вологого газу 31 кг палива в $\mathrm{HM}^{3}$.

Середня теплоємність вологого газу:

$$
\begin{aligned}
& c_{p . m .}=c_{p \mathrm{CO}_{2}} v_{\mathrm{CO}_{2}}+c_{p C O} v_{\mathrm{CO}}+c_{p \mathrm{H}_{2}} v_{\mathrm{H}_{2}}+ \\
& +c_{p \mathrm{H}_{2} \mathrm{O}} v_{\mathrm{H}_{2} \mathrm{O}}+c_{p \mathrm{~N}_{2}} v_{\mathrm{N}_{2}}+c_{p \mathrm{CH}_{4}} v_{\mathrm{CH}_{4}}+c_{p_{2} \mathrm{O}_{2}} v_{\mathrm{O}_{2}} \text {, }
\end{aligned}
$$

де: $c_{p}$ - середня теплоємність компонентів суміші,

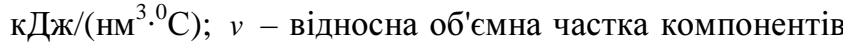
вологого газу.

Для зручності розрахунку в табл. 3 наведено емпіричні рівняння середньої об'ємної теплоємності різних газів і водяної пари.

Табл. 3. Середня об'ємна теплоємність 1 нм $^{3}$ різних газів i водяної пари за постійного тиску

\begin{tabular}{|c|c|c|}
\hline Газ & $\begin{array}{c}\text { Температурні ме- } \\
\text { жі застосування } \\
\text { рівняння, }{ }^{\circ} \mathrm{C}\end{array}$ & $\begin{array}{c}\text { Рівняння середньої } \\
\text { об'ємної теплоємності, } \\
\left.\text { кДж/(нм }{ }^{3}{ }^{\circ} \mathrm{C}\right)\end{array}$ \\
\hline Окис вуглецю & $100-1600$ & $1,292+0,000118 \cdot t$ \\
\hline $\begin{array}{c}\text { Двоокис } \\
\text { вуглецю }\end{array}$ & $100-800$ & $1,6739+0,000062 \cdot t$ \\
\hline Водень & $800-1700$ & $1,9713+0,000248 \cdot t$ \\
\hline Водяна пара & $100-1600$ & $1,2905+0,00000392 \cdot t$ \\
\hline Метан & $100-2000$ & $1,4681+0,000244 \cdot t$ \\
\hline Азот & - & $1,655+0,000934 \cdot t$ \\
\hline Кисень & $100-1600$ & $1,2884+0,000112 \cdot t$ \\
\hline Повітря & $100-1300$ & $1,3127+0,00016 \cdot t$ \\
\hline & $100-1600$ & $1,2942+0,000114 \cdot t$ \\
\hline
\end{tabular}

Для визначення теплових втрат з недопаленим вуглецем у золі, шлаку і пилі збирають за певний час відходи 3 газогенератора і визначаємо вміст у них золи $A_{u}^{c}$ і вологи $W_{u}^{p}$.

Кількість недопаленого вуглецю $C_{u}$ в кг у золі і шлаку на 1 кг палива визначаємо за рівнянням

$$
C_{u}=\frac{g_{u}}{\tau \cdot G_{n}}\left(\frac{100-W_{u}^{p}}{100}\right)\left(\frac{100-A_{u}^{c}}{100}\right),
$$

де: $\tau$ - час, упродовж якого назбиралося $g_{u}$ кг відходів, год; $G_{n}$ - витрата палива, кг/год.

Вмістом інших горючих елементів у відходах палива нехтуємо.

Кількість тепла, що міститься в недопаленому вуглеці золи і шлаку, становитиме:

$$
Q_{u}=33940 \cdot C_{u}, \text { кДж/кг палива. }
$$

Втрати тепла 3 пилом, що виноситься з газогенератора, незначні.

Вміст вуглецю в пилі знаходимо за рівнянням

$$
C_{n}=g_{n}\left(\frac{100-W_{n}^{p}}{100}\right)\left(\frac{100-A_{n}^{p}}{100}\right),
$$

де: $g_{n}$ - кількість пилу, що виноситься 3 газогенератоpa, кг/кг палива; $W_{n}^{p}$ - вміст вологи в пилі; $A_{n}^{p}-$ вміст золи в сухому пилі.

Кількість пилу, що виноситься з газогенератора:

$$
g_{n}=\frac{G_{n}}{\tau \cdot G_{T}}, \text { кг/кг палива, }
$$

де: $G_{n}$ - кількість пилу, зібраного у фільтрі за час $\tau$, кг; $\tau$ - час накопичення пилу у фільтрі, год; $G_{T}$ - витрата палива, кг/год.

Кількість тепла, що втрачається 3 вуглецем, який міститься в пилі:

$$
Q_{n}=33940 \cdot C_{n}, \text { кДж/кг палива. }
$$

Для визначення кількості пилу, що виноситься з газогенератора, зважують пил, що збирається у фільтрі.

Втратами тепла, що виноситься 3 газогенератора із смолою, нехтують, оскільки кількість смоли невелика і не перевищує 1 г/нм ${ }^{3}$ газу.

Коефіцієнт корисної дії газогенератора знаходимо 3 відношення нижчої теплотворності синтез-газу до нижчої теплотворності палива, витраченого для отримання газу:

$$
\eta_{2}=\frac{V_{c} Q_{H}^{c .2 .}}{Q_{H}^{p}}
$$

де: $V_{c}$ - вихід сухого синтез-газу палива, $\mathrm{Hм}^{3} / \kappa г ; Q_{H}^{c . z .}-$ нижча теплотворність сухого синтез-газу, кДж/нм ${ }^{3}$; $Q_{H}^{p}$ - нижча теплотворність робочого палива, кДж/кг.

Результати розрахунку матеріального і теплового балансів процесу газифікації деревини (на прикладі породи сосна). Складемо матеріальний і тепловий баланси на основі експериментальних досліджень процесу газифікації деревини породи сосна (Pinus sylvestris).

Склад подрібненої деревини породи сосна (Pinus sylvestris) в робочому стані: $C^{p}=28,4 \% ; H^{p}=5,2 \% ; O^{p}$ $=22,7 \% ; A^{P}=0,7 \% ; W^{p}=43 \%$. Нижча теплотворна здатність деревини породи сосна (Pinus sylvestris) рівна $Q_{H}{ }^{p}=11443$ кДж/кг.

У процесі газифікації деревини породи сосна (Pinus sylvestris) отримано сухий генераторний газ такого складу (дод. Б.1): $\mathrm{CO}=32,8 \% ; \mathrm{H}_{2}=25,9 \% ; \mathrm{CO}_{2}=$ $5,3 \% ; \mathrm{CH}_{4}=7,7 \% ; \mathrm{N}_{2}=28,1 \% ; \mathrm{O}_{2}=0,2 \%$. Нижча теплота згорання синтез-газу $Q_{H}=9875$ кДж/нм ${ }^{3}$. У фільтрі зібрано $G_{n}=2,2$ кг пилу за $\tau=5$ год роботи газогенератора. Відсоток золи в пилі - $A_{n}^{c}=80 \%$; вологість пилу $W_{n}^{p}=5 \%$. Витрата палива $G_{T}=21$ кг/год. Кількість відходів, зібраних у зольнику, дорівнює 0,096 кг/кг палива. 
Зольність відходів $A_{u}^{c}=72 \%$, вологість відходів (золи, шлаку) $W_{u}^{p}=2 \%$.

Визначимо втрати вуглецю із золи, шлаку і пилу, що вийшли з газогенератора.

Визначаємо спочатку кількість пилу, що виноситься 3 газогенератора:

$$
g_{n}=\frac{2,2}{5 \cdot 21}=0,02 \text { кг/кг палива. }
$$

Тоді вміст вуглецю в пилі дорівнює:

$$
C_{n}=0,02\left(\frac{100-5}{100}\right) \cdot\left(\frac{100-80}{100}\right)=0,0038 \text { кг. }
$$

Приймаючи, що $\frac{g_{u}}{\tau G_{T}}=0,096$ кг/кг палива, то вміст вуглецю в золі і шлаку буде дорівнювати:

$$
C_{u}=0,096 \cdot\left(\frac{100-2}{100}\right) \cdot\left(\frac{100-72}{100}\right)=0,0263 \text { кг. }
$$

Сумарна кількість вуглецю, втраченого на 1 кг палива:

$$
C_{\text {в.s. }}=0,0038+0,0263=0,0301 \text { кг/кг палива. }
$$

Вихід сухого газу з 1 кг деревини знаходимо за такою формулою:

$$
V_{C}=\frac{1,867(28,4-3,01)}{32,8+5,3+7,7}=1,035 \mathrm{Hм}^{3} / \text { кг. }
$$

Далі визначаємо вологість газу, враховуючи, що 3 дуттям пара не вводиться. При цьому нехтуємо вмістом вологи повітря, що всмоктується в газогенератор (кг/нм $\left.{ }^{3}\right)$ :

$$
\begin{gathered}
f_{\Gamma}=\frac{9}{1,035} \cdot\left[0,052+\frac{0,43}{9}-0,0899 \cdot(0,259+2 \cdot 0,077) \cdot 1,035\right]= \\
=0,533 .
\end{gathered}
$$

Такому вмісту вологи в газі відповідає такий об'єм водяної пари у вологому газі:

$$
V_{\mathrm{H}_{2} \mathrm{O}}=\frac{0,533 \cdot 22,4}{43}=0,277 \mathrm{~m}^{3} / \mathrm{Hм}^{3} \text { газу. }
$$

Склад вологого газу, що визначається перерахунком сухого газу на вологий, перемножуючи об'ємне значення кожного компонента сухого газу на $(100-27,7) / 100=$ 0,723 .

Отримаємо такий склад вологого газу: $\mathrm{CO}=$ $23,71 \%, \mathrm{CO}_{2}=3,83 \%, \mathrm{H}_{2}=18,72 \%, \mathrm{CH}_{4}=5,56 \%, \mathrm{H}_{2} \mathrm{O}$ $=27,7 \% ; \mathrm{N}_{2}=20,31 \% ; \mathrm{O}_{2}=0,14 \%$.

Визначимо питому масу вологого газу, підставляючи в рівняння значення питомої маси газу і об'ємний вміст газу у вологому стані:

$$
y_{\Gamma}=1,25 \cdot 0,2371+1,965 \cdot 0,0383+0,0899 \cdot 0,1872+
$$

$0,717 \cdot 0,0556+0,804 \cdot 0,277+1,25 \cdot 0,2031+1,429 \cdot 0,0014=$

$$
=0,91 \mathrm{\kappa г} / \mathrm{Hм}^{3} \text {. }
$$

Знаходимо вихід вологого газу з 1 кг палива:

$$
V_{B . \Gamma .}=1,035+\frac{0,533 \cdot 1,035}{0,804}=1,72 \mathrm{нм}^{3} / \text { кг палива. }
$$

Масова кількість вологого газу, що отримується 3 1 кг палива:

$$
g_{B . \Gamma .}=y_{\Gamma} \cdot V_{B . \Gamma .}=0,91 \cdot 1,72=1,56 \text { кг/кг палива. }
$$

\begin{tabular}{|c|c|c|c|}
\hline \multicolumn{2}{|c|}{ Прихід } & \multicolumn{2}{|c|}{ Витрата } \\
\hline Деревина & 1,00 кг & Вологий газ & $1,56 \kappa \Gamma$ \\
\hline Повітря & 0,788 кг & Зола і шлак & 0,096 кг \\
\hline & & Пил & 0,02 кг \\
\hline Всього & 1,788 кг & Всього & 1,676 кг \\
\hline
\end{tabular}

Знаходимо об'єм повітря, що витрачається під час газифікації 1 кг деревини, підставляючи величину $V_{B . \Gamma}$. на місце $V_{C .}$ :

$V_{\Pi}=N_{2}^{\Gamma} \cdot V_{C} / 0,79=0,28 \cdot 1,72 / 0,79=0,61 \mathrm{нм}^{3} /$ кг палива.(41)

Масова кількість повітря на 1 кг деревини:

$$
g_{n .}=y_{n} \cdot V_{n .}=1,293 \cdot 0,61=0,788 \text { кг/кг палива. }
$$

У табл. 4 складено матеріальний баланс процесу газифікації соснової деревини.
Табл. 4. Матеріальний баланс процесу газифікації соснової деревини

Знайдемо розбіжність у матеріальному балансі:

$$
\frac{1,788-1,676}{1,788} \cdot 100=6,2 \% \text {. }
$$

\begin{tabular}{|c|c|}
\hline \multicolumn{2}{|c|}{ Прихід тепла } \\
\hline Теплотворність палива & 11443 кДж/кг \\
\hline \multicolumn{2}{|c|}{ Витрата тепла } \\
\hline Теплотворність газу & $\begin{array}{c}9875 \text { кДж/нм }{ }^{3} \cdot 1,035 \text { нм}^{3} / \kappa г ~= \\
10220,62 \text { кДж/кг палива }\end{array}$ \\
\hline $\begin{array}{c}\text { Втрати тепла з пилом, } \\
\text { золою та шлаком }\end{array}$ & 1021,59 кДж/кг палива \\
\hline Інші втрати & 200,82 кДж/кг палива \\
\hline
\end{tabular}

Розбіжність у матеріальному балансі становить $6,2 \%$, що знаходиться в допустимих межах. Коефіцієнт корисної дії газогенератора становитиме:

$$
\eta_{2}=\frac{1,035 \cdot 9875}{11443}=0,89 .
$$

Теплові втрати з вуглецем, який міститься в пилі та золі і шлаку (кДж/кг):

$$
Q_{n}=33940 \cdot\left(C_{n}+C_{u}\right)=33940 \cdot(0,0038+0,0263)=1021,59 \text {. (45) }
$$

$\mathrm{У}$ табл. 5 складено тепловий баланс процесу газифікації деревини.

Табл. 5. Тепловий баланс процесу газифікації соснової деревини

3 теплового балансу бачимо, що під час газифікації соснової деревини невеликі втрати тепла виходять внаслідок винесення пилу і втрат вуглецю 3 золою і шлаком.

Обговорення результатів дослідження. Розроблено високоефективний газогенератор із суцільним шаром, що відрізняється від відомих конструкцій газогенераторів. Використання газогенераторів запропонованої конструкції дає змогу підвищити ефективність процесу термічного перероблення твердого палива в газоподібне паливо шляхом збільшення швидкості та інтенсивності процесу газифікації палива (Mysak, Lys \& Martynyak-Andrushko, 2017; Lys, 2017a, 2017b), а також вирішити проблеми екологічної утилізації промислових та побутових відходів деревини, отримання дешевої енергії та екологічного стану довкілля.

На основі аналізу теоретичних положень та експериментальних досліджень розроблено метод розрахунку процесу газифікації деревини, який дає змогу провести розрахунок параметрів робочого процесу в газифікаторі зі суцільним шаром, засновану на рівняннях теплового i матеріального балансів. Розбіжність у матеріальному балансі становить $1,4 \%$, що знаходиться в допустимих межах. 3 теплового балансу виходить, що під час газифікації соснової деревини невеликі втрати тепла виходять внаслідок винесення пилу і втрат вуглецю з золою і шлаком.

Дослідження $є$ продовженням роботи щодо підвищення ефективності процесу газифікації низькосортних палив у суцільному шарі як альтернатива спалюванню природного газу та газифікації вугілля і вони триватимуть в майбутньому.

Висновки. Проаналізовано фізичні моделі процесу газифікації твердого палива, які дають змогу побудувати методику розрахунку параметрів робочого процесу у 
газифікаторі, засновану на рівняннях теплового і матеріального балансів, вигорання і газифікації вуглецю, що сприяє підвищенню екологічних показників, скороченню термінів розроблення агрегатів, модернізації наявних інженерних методів розрахунку та проектування обладнання, пошуку оптимальних умов функціонування апаратів та раціональних шляхів використання палив.

Унаслідок проведених теоретичних та експериментальних досліджень розроблено метод розрахунку процесу газифікації деревини, який дає змогу провести розрахунок параметрів робочого процесу в газифікаторі зі суцільним шаром.

Складено матеріальний і тепловий баланси на основі експериментальних досліджень процесу газифікації деревини породи сосна (Pinus sylvestris). Розбіжність у матеріальному балансі становить $1,4 \%$, що знаходиться в допустимих межах. 3 теплового балансу виходить, що під час газифікації деревини невеликі втрати тепла виходять внаслідок винесення пилу і втрат вуглецю зі золою і шлаком.

\section{Перелік використаних джерел}

Al-Rahbi, Amal S., Onwudili, Jude A., \& Williams, Paul T. (2016). Thermal decomposition and gasification of biomass pyrolysis gases using a hot bed of waste derived pyrolysis char. Bioresource Technology, 204 ,

$71-79$ https://doi.org/10.1016/j.biortech.2015.12.016

Hejazi, Bijan, Grace, John R., Bi, Xiaotao, \& Mahecha-Botero, Andrés. (2017). Kinetic model of steam gasification of biomass in a bubbling fluidized bed reactor. Energy Fuels, 31(2), 1702-1711. https://doi.org/10.1021/acs. energyfuels.6b03161

Islam, Piash Mahmudul, Faruque, Hossain Md, \& Zakia, Parveen. (2016). Physico-chemical properties and nutrient content of some slow pyrolysis biochars produced from different feedstocks. Bangladesh Journal of Scientific Research, 29(2), 111-122. https://doi.org/10.3329/bjsr.v29i2.323

La Villetta, M., Costa, M., \& Massarotti, N. (2017). Modelling approaches to biomass gasification: A review with emphasis on the stoichiometric method. Renewable and Sustainable Energy Reviews, 74 71-78. https://doi.org/10.1016/j.rser.2017.02.027

Lopez, Gartzen, Alvarez, Jon, Amutio, Maider, Arregi, Aitor, Bilbao, Javier, \& Olazar, Martin. (2016). Assessment of steam gasification

kinetics of the char from lignocellulosic biomass in a conical spouted bed reactor. Energy, 107, 493-501. https://doi.org/10.1016/j.energy.2016.04.040

López-González, D., Fernandez-Lopez, M., Valverde, J. L., \& Sanchez-Silva, L. (2014). Gasification of lignocellulosic biomass char obtained from pyrolysis: Kinetic and evolved gas analyses. Energy, 71, 456-467. https://doi.org/10.1016/j.energy.2014.04.105

Lys, S. S. (2017a). Termichne pereroblennia nyzkosortnykh palyv u hazopodibne palyvo dlia vykorystannia $\mathrm{v}$ teploenerhetychnykh ustanovkakh. Scientific Bulletin of UNFU, 27(3), 145-147. https://doi.org/10.15421/40270332

Lys, S. S. (2017b). Analiz eksperymentalnykh doslidzhen protsesu hazyfikatsii nyzkosortnykh palyv. Scientific Bulletin of UNFU, 27(1), 154-156. https://doi.org/10.15421/40270136

Lys, S. S., \& Mysak, Y. S. (2012). Fizyko-khimichna model protsesu hazyfikatsii derevyny. Visnyk inzhenernoi akademii Ukrainy, 2, 301-304. [In Ukrainian].

Mingaleeva, G., Ermolaev, D., \& Galkeeva, A. (2016). Physico-chemical foundations of produced syngas during gasification process of various hydrocarbon fuels. Clean Technologies and Environmental Policy, 18, 297-304. https://doi.org/10.1007/s10098-015-0988-8

Moltó, Julia, Barneto, Agustín G., José, Ariza, \& Conesa, Juan A. (2013). Gas production during the pyrolysis and gasification of biological and physico-chemical sludges from oil refinery. Journal of Analytical and Applied Pyrolysis, 103, 167-172. https://doi.org/10.1016/j.jaap.2012.09.012

Mysak, Y., Lys, S., \& Martynyak-Andrushko, M. (2017). Research on gasification of low-grade fuels in a continuous layer. (Vol. 2). Eastern-European Journal of Enterprise Technologies, 8(86), 16-23. https://doi.org/10.15587/1729-4061.2017.96995

Tapas, Kumar Patra, \& Sheth, Pratik N. (2015). Biomass gasification models for downdraft gasifier: A state-of-the-art review. Renewable and Sustainable Energy Reviews, 50, 583-593. https://doi.org/10.1016/j.rser. 2015.05.012

Zhang, Yan, Zheng, Yan, Yang, Mingjun, \& Song, Yongchen. (2016). Effect of fuel origin on synergy during co-gasification of biomass and coal in $\mathrm{CO}_{2}$. Bioresource Technology, 200, 789-794. https://doi.org/10.1016/j.biortech. 2015.10.076

Zhiqiang, Wu., Shuzhong, Wang, Zhengyuan, Luo, \& Lin, Chen. (2017). Physico-chemical properties and gasification reactivity of co-pyrolysis char from different rank of coal blended with lignocellulosic biomass: Effects of the cellulose. Bioresource Technology, 235, 256-264. https://doi.org/10.1016/j.biortech.2017.03.121

S. S. Lys, M. M. Semerak, O. H. Yurasova Lviv Polytechnic National University, Lviv, Ukraine

\section{DEVELOPMENT OF A METHOD FOR CALCULATING THE PROCESS OF GASIFICATION OF LOW-GRADE FUELS IN A CONTINUOUS LAYER ON THE BASIS OF EXPERIMENTAL RESEARCH}

The composition and calorific value of the synthesis gas obtained as a result of gasification of low-grade fuel may vary depending on various factors. The main factors influencing the process of wood gasification are the size of the particles, the amount of air supplied to the gasification chamber, and a number of other factors depending on the gas that is gasified and the parameters of the gasifier. To date, the physical models of the solid fuel gasification process have been developed and covered in literary sources and scientific articles, which allow to construct a method for calculating the parameters of the working process in a gasifier based on the equations of thermal and material balances, the burning and carbonization of gas, and also heat exchange of particles with a layer and with the wall of the gas generator. However, these physical models are designed for a specific type of gasifier. Therefore, there is a need to develop a method for calculating the wood gasification process, which will allow calculation of the parameters of the working process in a gasifier with a continuous layer, which is most technologically and constructively simple. The main goal of the work is to develop a method for calculating the gasification process of low-grade fuel, which will allow the calculation of the parameters of the working process in a gasifier with a continuous layer, which is the most technologically and structurally simple. Used standardized methods for conducting research of the process of gasification of low-grade fuel. In the process of developing a gas generator plant, which allows the production of synthesis gas, modern methods of using appropriate monitoring devices are used. Used mathematical planning of experimental research. A method has been developed for calculating the process of wood gasification, which allows the calculation of the parameters of the working process in a gasifier with a continuous layer, based on the equations of heat and material balances. Based on experimental studies, the material and heat balance of the pine gasification gasification process (Pinus sylvestris) was compiled. It is shown that during gasification of pine wood, small heat losses are obtained as a result of dust removal and carbon losses with ash and slag.

Keywords: lower heat of combustion; synthesis gas; material and heat balance; gasification of low-grade fuel. 